\title{
Ryegrass control derived from isolated application with herbicides association
}

\section{Controle de azevém decorrente da aplicação isolada e em associação de herbicidas}

\section{Ana Paula ROCKENBACH ${ }^{1}$; Theodoro SCHNEIDER ${ }^{2}$; Mario Antônio BIANCHI ${ }^{3}$}

${ }^{1}$ Autor para correspondência (corresponding author); Engenheira Agrônoma, Mestranda do Programa de Pós Graduação em Agronomia, Agricultura e Ambiente (PPGAAA); Centro de Educação Superior Norte - RS, Universidade Federal de Santa Maria; Departamento de Ciências Agronômicas e Ambientais; Linha Sete de Setembro, s/n, - BR 386 KM 40, CEP 98400-000, Frederico Westphalen/RS. anapagronomia@yahoo.com.br

${ }^{2}$ Engenheiro Agrônomo, Mestrando do Programa de Pós Graduação em Fitossanidade; Universidade Federal de Pelotas; theodoroschneider@hotmail.com

${ }^{3}$ Engenheiro Agrônomo, Dr., Professor da Universidade de Cruz Alta e Pesquisador da CCGL Tecnologia; mario.bianchi@ccgl.com.br

Recebido em: 22-04-2014; Aceito em: 03-12-2014

\begin{abstract}
The objective of this work was to evaluate the efficiency of herbicides from different mechanism of action, isolate and in association in ryegrass control. The trial was conducted during the cool station in 2010 at field station of University of Cruz Alta located in Cruz Alta/RS. The treatments evaluated were: glyphosate $\left(720,1440\right.$ and $2160 \mathrm{~g}$ a.e. ha $\left.{ }^{-1}\right)$, fluazifop-butyl $\left(200 \mathrm{~g} \mathrm{ha}^{-1}\right)$, clethodim $\left(72 \mathrm{~g} \mathrm{ha}^{-1}\right)$, quizalofop-p-ethyl $\left(120 \mathrm{~g} \mathrm{ha}^{-1}\right)$, clodinafop-propargyl $\left(120 \mathrm{~g} \mathrm{ha}^{-1}\right)$, glufosinate $\left(500 \mathrm{~g} \mathrm{ha}^{-1}\right)$, paraquat $\left(500 \mathrm{~g} \mathrm{ha}^{-1}\right)$, the associations of glyphosate $\left(720 \mathrm{~g}\right.$ a.e. ha $\left.{ }^{-1}\right)$ with fluazifop-butyl $\left(125\right.$ and $\left.200 \mathrm{~g} \mathrm{ha}^{-1}\right)$, clodinafop-propargyl $\left(60\right.$ and $\left.120 \mathrm{~g} \mathrm{ha}^{-1}\right)$, quizalofop-p-ethyl $\left(96 \mathrm{~g} \mathrm{ha}^{-1}\right)$, clethodim $\left(72 \mathrm{~g} \mathrm{ha}^{-1}\right)$, and a control without treatment. The treatment with glyphosate+clethodim $\left(720+72 \mathrm{~g} \mathrm{ha}^{-1}\right)$ and glyphosate+quizalofop-p-ethyl were the positive highlights in ryegrass control.The ACCase inhibitors applied alone were not a good control option; however, the increase of glyphosate dose until $2160 \mathrm{~g}$ a.e. ha ${ }^{-1}$ improved the ryegrass control. The paraquat herbicide showed good control results, being superior to glufosinate, though both products results are not insurance for indicate your use alone. Associations of glyphosate with clethodim or quizalofop-p-ethyl and the increase of glyphosate dose proved an increment in control efficiency and reduced the ryegrass dry matter, constituting in viable options to control this specie.
\end{abstract}

Additional keywords: clethodim; fluazifop-butyl; Lolium multiflorum; quizalofop-p-ethyl; weed.

\section{Resumo}

Objetivou-se com este trabalho avaliar a eficiência de herbicidas de diferentes mecanismos de ação, isolados e em associação, no controle de azevém. O trabalho foi conduzido durante a estação fria de 2010 na área experimental da Universidade de Cruz Alta situada no município de Cruz Alta/RS. Os tratamentos avaliados foram: glifosato $\left(720,1440\right.$ e $2160 \mathrm{~g}$ e. a. ha $\left.{ }^{-1}\right)$, fluazifope-p-butílico $\left(200 \mathrm{~g} \mathrm{ha}^{-1}\right)$, cletodim $\left(72 \mathrm{~g} \mathrm{ha}^{-1}\right)$, quizalofope-p-tefurílico $\left(120 \mathrm{~g} \mathrm{ha}^{-1}\right)$, clodinafope $\left(120 \mathrm{~g} \mathrm{ha}^{-1}\right)$, glufosinato $\left(500 \mathrm{~g} \mathrm{ha}^{-1}\right)$, paraquate $\left(500 \mathrm{~g} \mathrm{ha}^{-1}\right)$, as associações de glifosato $\left(720 \mathrm{~g}\right.$ e.a. ha $\left.{ }^{-1}\right)$ com fluazifope-p-butílico $\left(125 \mathrm{e} 200 \mathrm{~g} \mathrm{ha}^{-1}\right)$, clodinafope $\left(60 \mathrm{e} 120 \mathrm{~g} \mathrm{ha}^{-1}\right)$, quizalofope-p-tefurílico $\left(96 \mathrm{~g} \mathrm{ha}^{-1}\right)$, cletodim (72 $\left.\mathrm{g} \mathrm{ha}^{-1}\right)$, e uma testemunha sem aplicação de herbicida. $\mathrm{O}$ tratamento com glifosato + cletodim $\left(720+72 \mathrm{~g} \mathrm{ha}^{-1}\right)$ e com glifosato + quizalofope-p-telurílico, destacaram-se positivamente no controle do azevém. Os inibidores de ACCAse isolados não foram boas opções de controle, por outro lado, o aumento da dose de glifosato até $2160 \mathrm{~g} \mathrm{e}$. a. ha ${ }^{-1}$ melhorou o controle de azevém. O herbicida paraquate apresentou bons resultados de controle, sendo superior ao glufosinato, porém o resultado de ambos os produtos não são suficientes para indicar seu uso isoladamente. Associações do glifosato com cletodim ou quizalofope-p-tefurílico e o aumento da dose de glifosato, proporcionaram acréscimos na eficiência de controle e reduziram a massa seca do azevém, constituindo-se em opções viáveis para o controle desta espécie.

Palavras-chave adicionais: cletodim; fluazifope-p-butílico; Lolium multiflorum; planta daninha; quizalofope-p-tefurílico. 


\section{Introduction}

Weed and crops used as ground cover burn down practice is important for a crop proper establishment. The presence of weeds remnant from burn down or from a new emergency flow, simultaneously with emergence culture, causes damage both in the quantity and quality of harvested grains (CAMPOS et al., 2012). Especially in wheat and corn crops, the ryegrass (Lolium multiflorum), a forage annual species native of southern Europe, constitutes one of the main weed species in southern Brazil. In the soybean culture, it is important in crops grown at the beginning of October in Rio Grande do Sul. Glyphosate stands out as the most widely used herbicide for ryegrass control before wheat, corn and soybean sowing under no-tillage system.

Glyphosate inhibits the EPSPS (5enolpyruvylshikimate 3-phosphate synthase) enzyme, which participates in amino acids synthesis route(RUAS et al., 2012). Enzyme inhibition results in shikimic acid accumulation in plants and in the reduction of aromatic amino acids phenylalanine, tyrosine and tryptophan synthesis (MOREIRA et al., 2010). This herbicide has a broad weeds control spectrum, relatively low cost, high efficiency over different species and ease of application (VARGAS et al., 2004). Furthermore, its use expands when it comes to genetically modified crops resistant to glyphosate (MELO et al., 2012). Intensive glyphosate use, besides increasing resistant plants selection risk, also causes weed change, due to selection of species with increased tolerance to the product (MOREIRA et al., 2010).

The low use of effective herbicides on ryegrass with glyphosate alternative mechanisms of action intensifies resistant biotypes selection process. The biggest problems are noticed in burn down preceding seeding and are related to glyphosate individual use in ryegrass control. In Brazil, this species has biotypes resistant to EPSPS inhibitors and biotypes resistant to ALS inhibitors, besides having resistance to both EPSPS inhibitors and ACCase inhibitors in the same biotype (HEAP, 2014).

The control of ryegrass resistant biotypes to glyphosate resides in the use of effective herbicides belonging to alternative mechanism of action, such as Acetyl Coenzyme A carboxylase (ACCase), Glutamine synthetase (GS), photosystem I, acetolactate synthase (ALS), mitosis and photosystem 2 inhibitors (ROMAN et al., 2004). These mechanisms of action herbicides can be use alone or, if possible, in combination with glyphosate.

When it comes to herbicides associations, it should be considered that this can result in antagonism, synergism or neutral effect, con- sequences of chemical, physiological or kinetic interactions between products (VIDAL et al., 2010). In addition, weed species respond differently to herbicides when isolated or in combination (BARROSO et al., 2010) and in different weed plant stages. The more advanced the stage is, higher will be the herbicide dose required for an efficient control (DORS et al., 2010). Glyphosate is registered to control ryegrass at doses between 720 and $2160 \mathrm{~g}$ of acid equivalent (a.e.) $\mathrm{ha}^{-1}$, depending on the developmental plant stage (AGROFIT, 2014).

The objective of this study was to evaluate the efficiency of different mechanisms of action, alone and in combination, in ryegrass control.

\section{Material and methods}

The work was conducted during 2010 cold season, at field station of University of Cruz Alta, located in the city of Cruz Alta, northwestern region of Rio Grande do Sul state, Brazil, with $452 \mathrm{~m}$ altitude and the site soil being a clayey typic dystrophic Red Latosol (EMBRAPA, 2006). The experimental design was a randomized block with five repetitions. The plots were $4 \mathrm{~m}$ wide and $7 \mathrm{~m}$ long, and the herbicide was applied in $3 \mathrm{~m}$, leaving $1 \mathrm{~m}$ on each side of the plot as check. The assessed treatments are presented in Table 1. Herbicides were applied on 07-30-2010 on ryegrass plants with 5-6 tillers. To spray herbicide syrup, a pressurized backpack sprayer with $\mathrm{CO}_{2}$ at $103.5 \mathrm{kPa}$, a spray bar width of $3 \mathrm{~m}$, six fan type points (TT 110015) and spray volume equivalent to $115 \mathrm{~L} \mathrm{ha}^{-1}$ was used.

Efficiency control and ryegrass dry matter were determined. The control efficiency was visually assessed at 7, 14, 21, 28 and 42 days after treatment application (DAT), with final values represented by the averages of three evaluators. For this, the percentage scale where "0" represents control absence and "100" represents full control was used. Remaining plants dry matter was evaluated 59 days after herbicide application (DAT), with plant collection in a $1 \mathrm{~m}^{-2}$ area, and then putting it to dry in an oven at $60^{\circ} \mathrm{C}$, up to constant weight.

With average data at 42 DAT, increase in control efficiency (AEC) was calculated, considering the average control efficiency in glyphosate treatment at $720 \mathrm{~g}$ a.e.ha ${ }^{-1}$ (AEC1) and with glyphosate at $1440 \mathrm{~g}$ a.e.ha ${ }^{-1}$ (SCA2), as follows:

$$
\mathrm{AEC}=\mathrm{ECt}-\mathrm{EMCtr}
$$

Where ECt is the control efficiency in the desired treatment and EMCtr the control average efficiency in the glyphosate treatment, with negative values replaced by zero. 
Table 1 - Treatments evaluated, doses and commercial names. UNICRUZ, Cruz Alta/RS, 2010.

\begin{tabular}{|c|c|c|}
\hline Treatment & Dose $\left(\mathrm{g} \mathrm{ha}^{-1}\right)$ & Commercial name \\
\hline Glyphosate (Gly) & 720 & Zapp Q|® (500 g e.a. $\left.L^{-1}\right)$ \\
\hline Glyphosate & 1440 & Zapp Q|® $\left(500\right.$ g e.a. $\left.\mathrm{L}^{-1}\right)$ \\
\hline Glyphosate & 2160 & Zapp Q|® $\left(500\right.$ g e.a. $\left.\mathrm{L}^{-1}\right)$ \\
\hline Fluazifop-p-butyl & 200 & Fusilade $250 \mathrm{EW} \circledast\left(250 \mathrm{~g} \mathrm{~L}^{-1}\right)$ \\
\hline Clethodim & 72 & Select $\circledast\left(240 \mathrm{~g} \mathrm{~L}^{-1}\right)$ \\
\hline Quizalofop-p-tefuril & 120 & Panther $120 \mathrm{EC} \circledast\left(120 \mathrm{~g} \mathrm{~L}^{-1}\right)$ \\
\hline Clodinafop & 120 & Topik $240 \mathrm{EC} \circledast\left(240 \mathrm{~g} \mathrm{~L}^{-1}\right)$ \\
\hline Gly + fluazifop-p-butyl & $720+125$ & Zapp Q|® $\left(500\right.$ g e.a. $\left.\mathrm{L}^{-1}\right)+$ Fusilade $250 \mathrm{EW} \circledast\left(250 \mathrm{~g} \mathrm{~L}^{-1}\right)$ \\
\hline Gly + fluazifop-p-butyl & $720+200$ & Zapp Q|® $\left(500\right.$ g e.a. $\left.\mathrm{L}^{-1}\right)+$ Fusilade $250 \mathrm{EW} \circledast\left(250 \mathrm{~g} \mathrm{~L}^{-1}\right)$ \\
\hline Gly +Clodinafop & $720+60$ & Zapp Q|® $\left(500\right.$ g e.a. $\left.L^{-1}\right)+$ Topik 240 EC® $\left(240 \mathrm{~g} \mathrm{~L}^{-1}\right)$ \\
\hline Gly +Clodinafop & $720+120$ & Zapp Q|® $\left(500\right.$ g e.a. $\left.L^{-1}\right)+$ Topik 240 EC® $\left(240 \mathrm{~g} \mathrm{~L}^{-1}\right)$ \\
\hline Gly +Quizalofop-p-tefuril & $720+96$ & Zapp Q|® (500 g e.a. $\left.\mathrm{L}^{-1}\right)+$ Panther $120 \mathrm{EC} \circledast\left(120 \mathrm{~g} \mathrm{~L}^{-1}\right)$ \\
\hline Gly +Clethodim & $720+72$ & Zapp QI® $\left(500\right.$ g e.a. L $\left.^{-1}\right)+$ Select@ $\left(240\right.$ g L$\left.^{-1}\right)$ \\
\hline Glufosinate & 500 & Finale $\AA\left(200 \mathrm{~g} \mathrm{~L}^{-1}\right)$ \\
\hline Paraquat & 500 & Gramoxone $200 \circledast\left(200 \mathrm{~g} \mathrm{~L}^{-1}\right)$ \\
\hline Check & 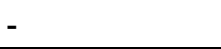 & \\
\hline
\end{tabular}

The control efficiency data, converted to $\operatorname{arc} \sin \sqrt{ } \mathrm{x} / 100$, and plants dry matter were subjected to analysis of variance. For significant differences by $F$ test $(p=0.05)$, averages were compared by Scott-Knott test $(p=0.05)$. In the tables, control efficiency results are presented as a percentage, although the mean comparison test and the coefficient of variation refer to processed data.

\section{Results and discussions}

The action of the isolated glyphosate in7 DAT evaluation was generally low (Table 2). According to CAMPOS et al. (2012), this occurs due to the relatively slow action of this herbicide, as it presents systemic action and demands a longer time to show symptoms, which can be seen in the following evaluations, where glyphosate increased its level control. In lack of this knowledge, plants are often considered resistant.

At 14 DAT, glyphosate showed a significant increase in control level with the increase of $720(58 \%)$ to $2160 \mathrm{~g}$ e.a. ha ${ }^{-1}(86 \%)$ in the dose. This performance was maintained at 21 and 28 DAT and was consolidated at 42 DAT, where control level was of $68 \%$ at $720 \mathrm{~g}$ e.a. ha ${ }^{-1}$, rising to $87 \%$ at a $1440 \mathrm{~g}$ e.a. ha ${ }^{-1}$ dose and reaching $90 \%$ at a $2160 \mathrm{~g}$ e. a. ha ${ }^{-1}$ dose, characterizing control efficiency with the increase of this herbicide dose, which corroborates with DORS et al. (2010) data, who working with different glyphosate rates, and tworyegrass genotypes (diploid and tetraploid), observed an increase in the control level by increasing glyphosate herbicide dose. These results show that although requiring high doses, the evaluated ryegrass biotype is sensitive to glyphosate.
The intensive use of this herbicide molecule can bring consequences to its control efficiency, as the lack of mechanisms of action rotation may increase the tolerance and resistance cases, besides that recommended doses which would effectively control the species before could lose its effectiveness. This can be seen in this work through a better glyphosate control over ryegrass when increasing this herbicide dose.

An alternative for ryegrass control with mechanisms of action rotation is the use of ACCase inhibitors, which can be applied alone or in combination with other herbicides, including glyphosate. These, when applied in isolation, showed early control level differentiation at 14 DAT (Table 2), even if below $50 \%$, which was consolidated at 28 DAT, where clethodim and quizalofop-p-tefurilherbicides were highlighted and, at 42 DAT, this 85 and $83 \%$ control advantage was maintained, comparing to fluazifop-p-butyl and clodinafop (54 and $30 \%$ of control).

Among ACCase inhibitors, only clethodim and quizalofop-p-tefuril reached control levels similar to that of glyphosate at 28 and 42 DAT, at 720 and $1440 \mathrm{~g}$ e.a. ha ${ }^{-1}$ doses. However, they needed more time to achieve this level of control when compared to these two doses, and always provided lower levels of control compared to glyphosate $2160 \mathrm{~g}$ e.a. ha ${ }^{-1}$. ACCase inhibitors application alone was not effective in controlling ryegrass, as besides taking more time, control always proved to be lower than that of its associations with glyphosate. So, the option for effective control, especially in areas where there are no resistant plants presence knowledge, to prevent emergence, is the association of ACCase inhibitors with other herbicides, including glyphosate. 
Associations proved to be superior or equal to the other treatments virtually in all evaluations, showing to be an efficient alternative for ryegrass control. Glyphosate + clethodim (720 $\mathrm{g} \mathrm{e.a} \mathrm{ha}^{-1}+72 \mathrm{~g} \mathrm{ha}^{-1}$ ) association was superior in most evaluations, consolidating its efficiency at 28 DAT, when 94\% control was presented and maintained until 42 DAT. Glyphosate + fluazifop-p-butyl (720 g e.a. ha ${ }^{-1}+$ $+200 \mathrm{~g} \mathrm{ha}^{-1}$ ) and glyphosate + quizalofop-p-tefuril (720 g e. a. ha ${ }^{-1}+96 \mathrm{~g} \mathrm{ha}^{-1}$ ) associations also showed superiority in several evaluations, and along with clethodim association, were effective alternatives to ryegrass control.

At 21 DAT, the best glyphosate $(2160 \mathrm{~g} \mathrm{e}$. a. ha $\left.{ }^{-1}\right)$, glyphosate + fluazifop-p-butyl (720 g e. a. $\mathrm{ha}^{-1}+200 \mathrm{~g} \mathrm{ha}^{-1}$ ) and glyphosate + clethodim (720 g e. a. ha $^{-1}+72 \mathrm{~g} \mathrm{ha}^{-1}$ ) treatments provided control levels greater or equal to $93 \%$. It was observed that the combination of herbicide molecules and the increase of glyphosate doses were favorable to ryegrass control, as observed by MELO et al. (2012), which evaluating the effectiveness of alternative herbicides to control Digitaria insularis in glyphosate-resistant biotypes of citrus crop, obtained in herbicidal associations the best controls, and paraquat + diuron, and glufosinate were sequential handling important alternatives in glyphosate (1440 g e.a. ha $\left.{ }^{-1}\right)+$ clethodim (108 $\left.\mathrm{g} \mathrm{ha}^{-1}\right)$ treatment.
High paraquat control can be observed at 7 DAT, when it was the best treatment, with $89 \%$ control level, where other control treatments showed less than $60 \%$ (Table 2). At 14 DAT, paraguat remained among the herbicides that offered better control. However, even keeping control level above $80 \%$ in the following evaluations, other herbicides or associations were superior. In each evaluation, it can be observed that among herbicides with low plant mobility (contact herbicides), paraquat (500 $\mathrm{g} \mathrm{ha}^{-1}$ ) was in the group of the best treatments in all evaluations, with a final control at 42 DAT of $87 \%$, which is statistically equal to some of the treatments with herbicide association.

Another herbicide with low plant mobility used, glufosinate $\left(500 \mathrm{~g} \mathrm{ha}^{-1}\right)$, presented a generally low control efficiency, even among the best treatments at 7 and 14 DAT, although values were lower than what was expected. This low overall performance can be explained by its climate requirement, as according to MARCHI et al. (2008), this herbicide presents symptoms at a reduced rate if soon after application the weather is not sunny, so that light is involved in some way in the activity expression of this herbicide. What can be observed is that the weather was cloudy after treatment application, and it may have harmed the action of this herbicide.

Table 2 - Efficiency of ryegrass control (Lolium multiflorum) at 7, 14, 21, 28 and 42 days after treatments applications (DAT). UNICRUZ, Cruz Alta, 2010.

\begin{tabular}{lcccccccc}
\hline \multirow{2}{*}{ Treatments $^{1,2}$} & $\begin{array}{c}\text { Dose } \\
\left(\mathrm{g} \mathrm{ha}^{-1}\right)\end{array}$ & $7 \mathrm{DAT}$ & $14 \mathrm{DAT}$ & $21 \mathrm{DAT}$ & $28 \mathrm{DAT}$ & $42 \mathrm{DAT}$ \\
\hline Glyphosate (Gly) & 720 & 22 & $\mathrm{e}^{3}$ & $58 \mathrm{c}$ & $73 \mathrm{~d}$ & $68 \mathrm{c}$ & $68 \mathrm{c}$ \\
Gyphosate & 1440 & $26 \mathrm{~d}$ & $79 \mathrm{~b}$ & $91 \mathrm{~b}$ & $86 \mathrm{~b}$ & $87 \mathrm{~b}$ \\
Glyphosate & 2160 & $26 \mathrm{~d}$ & $86 \mathrm{a}$ & $95 \mathrm{a}$ & $93 \mathrm{a}$ & $90 \mathrm{a}$ \\
Fluazifop-p-butyl & 200 & $8 \mathrm{f}$ & $12 \mathrm{f}$ & $21 \mathrm{~h}$ & $40 \mathrm{~d}$ & $54 \mathrm{~d}$ \\
Clethodim & 72 & $10 \mathrm{f}$ & $26 \mathrm{~d}$ & $47 \mathrm{f}$ & $65 \mathrm{c}$ & $86 \mathrm{~b}$ \\
Quizalofop-p-tefuril & 120 & $8 \mathrm{f}$ & $15 \mathrm{e}$ & $30 \mathrm{~g}$ & $60 \mathrm{c}$ & $83 \mathrm{~b}$ \\
Clodinafop & 120 & $7 \mathrm{f}$ & $12 \mathrm{f}$ & $19 \mathrm{~h}$ & $35 \mathrm{~d}$ & $30 \mathrm{e}$ \\
Gly +Fluazifope-p-butyl & $720+125$ & $28 \mathrm{c}$ & $80 \mathrm{~b}$ & $91 \mathrm{~b}$ & $88 \mathrm{~b}$ & $87 \mathrm{~b}$ \\
Gly +Fluazifope-p-butyl & $720+200$ & $28 \mathrm{c}$ & $85 \mathrm{a}$ & $95 \mathrm{a}$ & $94 \mathrm{a}$ & $89 \mathrm{~b}$ \\
Gly +Clodinafop & $720+60$ & $25 \mathrm{~d}$ & $77 \mathrm{~b}$ & $91 \mathrm{~b}$ & $85 \mathrm{~b}$ & $87 \mathrm{~b}$ \\
Gly +Clodinafop & $720+120$ & $25 \mathrm{~d}$ & $77 \mathrm{~b}$ & $89 \mathrm{~b}$ & $90 \mathrm{~b}$ & $86 \mathrm{~b}$ \\
Gly +Quizalofop-p-tefuril & $720+96$ & $23 \mathrm{e}$ & $77 \mathrm{~b}$ & $91 \mathrm{~b}$ & $94 \mathrm{a}$ & $93 \mathrm{a}$ \\
Gly +Cletodim & $720+72$ & $31 \mathrm{c}$ & $87 \mathrm{a}$ & $93 \mathrm{a}$ & $94 \mathrm{a}$ & $94 \mathrm{a}$ \\
Glufosinate & 500 & $59 \mathrm{~b}$ & $74 \mathrm{~b}$ & 63 & $\mathrm{e}$ & $63 \mathrm{c}$ & $69 \mathrm{c}$ \\
Paraquat & 500 & $89 \mathrm{a}$ & $83 \mathrm{a}$ & $79 \mathrm{c}$ & $85 \mathrm{~b}$ & $87 \mathrm{~b}$ \\
\hline \multicolumn{1}{c}{ Coefficient of variation $(\%)$} & 6.2 & 3.7 & 3.6 & 5.0 & 4.9 \\
\hline
\end{tabular}

To herbicides, Nimbus mineral oil $\left(500 \mathrm{~mL}\right.$ ha $\left.{ }^{-1}\right)$ was added; ${ }^{2}$ Glyphosate is expressed in acid equivalent; ${ }^{3}$ Means followed by the same letter in the column do not differ by among them by Scott-Knott test $(p=0.05)$. Statistical analysis was performed with data converted to arc $\sin \sqrt{ } \mathrm{x} / 100$. 
MELO et al. (2012) found that paraquat and glufosinate herbicides do not have the same flexibility of glyphosate, demanding proper care especially at application time and weed stage. The most common use of these herbicides is in sequential applications, to complement glypho- sate action, or with other products. In addition, glufosinate has gained importance mainly by the possibility of mechanisms of action rotation, being an important strategy in the proper management of crops, avoiding resistance, as elucidated by GEMELLI et al. (2013).
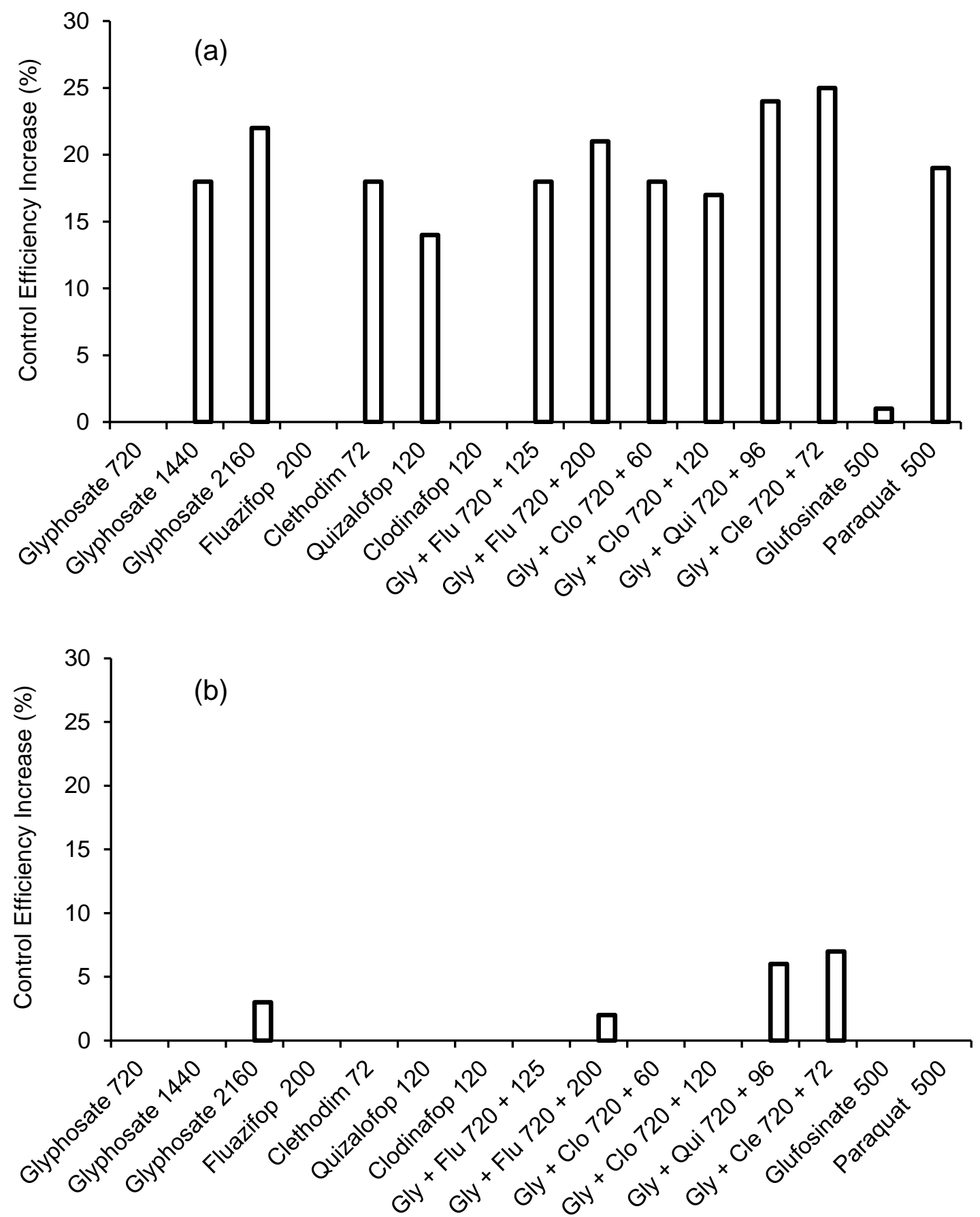

To herbicides, Nimbus mineral oil $\left(500 \mathrm{~mL} \mathrm{ha}^{-1}\right)$ was added; Means followed by the same letter in the column do not differ among them by Scott-Knott test $(p=0.05)$. Statistical analysis was performed with data converted to arc $\sin \sqrt{ } \mathrm{x} / 100$.Gly: glyphosate; Flu: fluazifop; Clo: clodinafop; Qui: quizalofop; Cle: clethodim.

Figure 1 - Efficiency increase of ryegrass control (Lolium multiflorum) at 42 days after the treatments application (DAT), mean values dose $720 \mathrm{~g}$ e.a. ha ${ }^{-1}(\mathrm{a})$; dose $1440 \mathrm{~g}$ a.e ha ${ }^{-1}(\mathrm{~b})$. UNICRUZ, Cruz Alta/RS 2010. 
For an increase in control efficiency, it is observed that at 42 DAT, there was a control increase compared to glyphosate $\left(720 \mathrm{~g} \mathrm{e.} \mathrm{a.} \mathrm{ha}{ }^{-1}\right)$ (Figure 1a) for glyphosate + clethodim $(720 \mathrm{~g} \mathrm{e}$. a. $\mathrm{ha}^{-1}+72 \mathrm{~g} \mathrm{ha}^{-1}$ ) and glyphosate + quizalofop-p-tefuril (720 g e.a. ha ${ }^{-1}+96 \mathrm{~g} \mathrm{ha}^{-1}$ ), followed by glyphosate $\left(2160 \mathrm{~g}\right.$ e. a. ha $\left.{ }^{-1}\right)$ and glyphosate + + fluazifop-p-butyl (720 g e.a. ha $\left.{ }^{-1}+200 \mathrm{~g} \mathrm{ha}^{-1}\right)$ treatments. The other variables also demonstrated increased control, with no statistical differences from ACCase inhibitors applied alone, clethodim and quizalofop-p-tefuril. Fluazifop-p-butyl and Clodinafop, when applied alone, did not show any increase, but when combined with glyphosate, benefited. In general, glyphosate alone or in combination showed an increase in control efficiency, in response to increasing the dose from 1440 to $2160 \mathrm{~g} \mathrm{e}$. a. ha ${ }^{-1}$. When compared to the $720 \mathrm{~g}$ e. a. ha ${ }^{-1}$ dose, paraquat herbicide showed a control increase of $19 \%$, equaling other treatments, which demonstrates that its ryegrass control is efficient.

When compared to a glyphosate dose of $1440 \mathrm{~g}$ e. a. ha ${ }^{-1}$ (Figure 1b), glyphosate + clethodim and glyphosate + quizalofop-p-tefuril showed to be better than other treatments, followed by glyphosate + fluazifop-p-butyl and glyphosate at $2160 \mathrm{~g}$ e. a. ha ${ }^{-1}$. However, this increase was not as significant as before at a $720 \mathrm{~g}$ e. a. ha ${ }^{-1}$ dose, showing that the increase of the glyphosate herbicide dose provided greater control. Treatments that showed the highest increase in control efficiency also had the lowest dry matter at 59 DAT (Figure 2), but all treatments decreased ryegrass dry matter, compared to the check without herbicides (166 g). However, clodinafop alone showed the highest ryegrass plants dry matter, followed by fluazifop-p-butyl and glufosinate, thus presenting the lowest species growth suppression.

Glyphosate (1440 e 2160 g e. a. ha $\left.{ }^{-1}\right)$, clethodim, quizalofop-p-tefuril and glyphosate associations (720 g e.a. ha ${ }^{-1}$ ) with ACCase inhibitors and paraquat had the largest dry matter reductions. On the other hand, clethodimand quizalofop-p-tefuril herbicides were indifferent to its association with glyphosate $\left(720 \mathrm{~g}\right.$ e.a. ha $\left.{ }^{-1}\right)$, being statistically equal, dry matter reduction was similar in both conditions of application, individually or in association.

For practical purposes, the use of other herbicides besides glyphosate, alone or in combination, should be an important tool for mechanism of action rotation in the field, besides preventing resistance to a particular molecule, as susceptible and resistant genotypes presence is common in many areas, and with herbicide use only, there would not be efficient control.

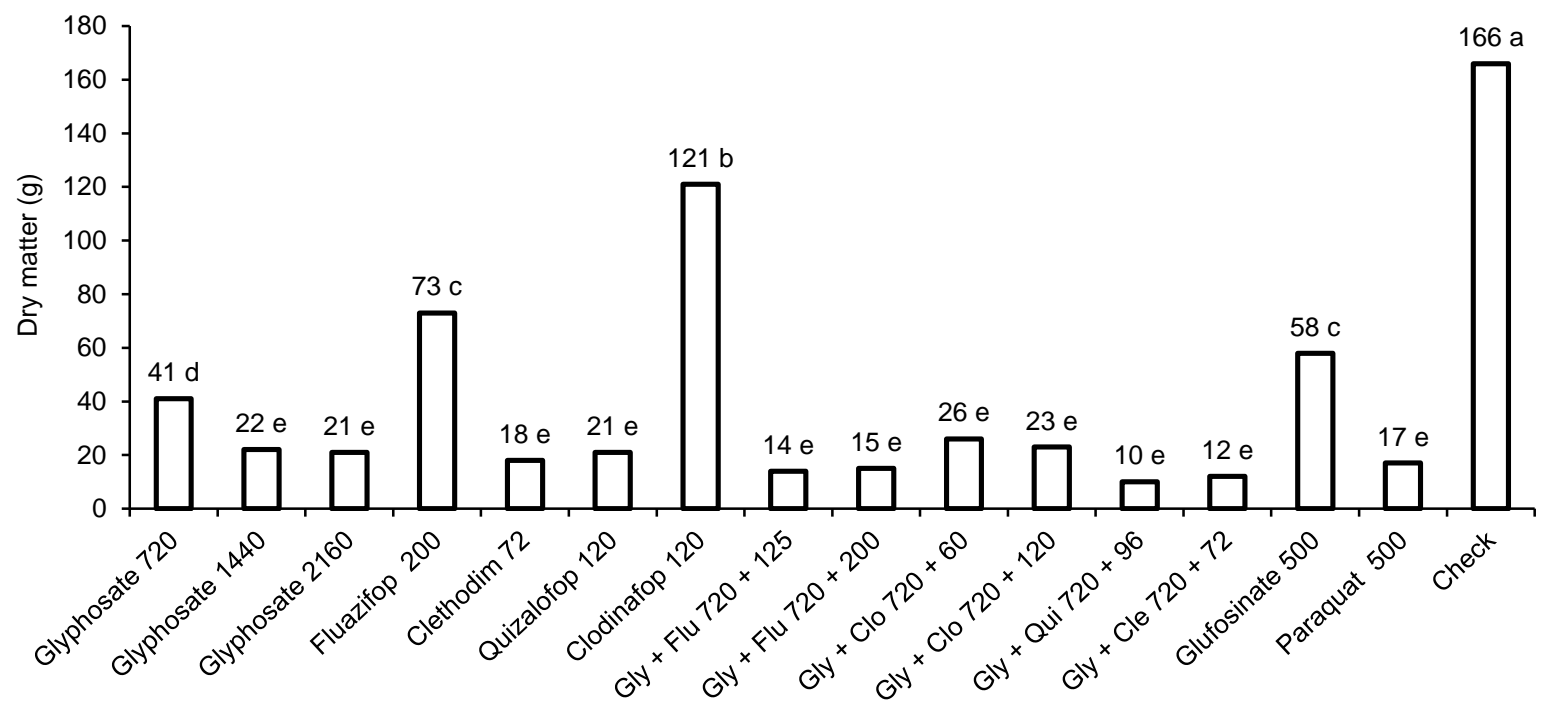

To herbicides, Nimbus mineral oil ( $500 \mathrm{~mL} \mathrm{ha}^{-1}$ ) was added; Means followed by the same letter in the column do not differ among them by Scott-Knott test $(p=0.05)$. Statistical analysis was performed with data converted to arc $\sin \sqrt{ } \times / 100$. Gly: glyphosate; Flu: fluazifop; Clo: clodinafop; Qui: quizalofop; Cle: clethodim.

Figure 2 - Dry matter of ryegrass plants (Lolium multiflorum) remaining of herbicides application at 59 days after the treatments applications. UNICRUZ, Cruz Alta/RS, 2010.

As these biotypes have similar morphology, resistant identification will only occur with the correct application of glyphosate in the area, that is, considering weather conditions, dose, spray volume, among others, so that resistant biotype scan actually be identified. According to GALVAN et al. (2011), while working with comparison evaluations of the resistant ryegrass susceptible to 
glyphosate, it was observed that it is not possible to distinguish it morphologically, although phenology was differentiated, because the susceptible biotype showed up earlier than the resistant. Thus, the initial control of all biotypes is very important as being easier controlled in the early stages, so it will not pass flowering stage, and consequently will not produce seeds, reducing the seed bank in the area and weed incidence.

\section{Conclusions}

The increase in glyphosate dose improves ryegrass control level.

The isolate application of ACCase inhibitors is not viable to ryegrass control. However, it was a viable option when associated with glyphosate, especially with clethodim and quizalofop-p-tefuril.

The paraquat and glufosinate herbicides are not good alternatives to isolated application, highlighting its importance in sequential application.

\section{References}

AGROFIT. Sistema de agrotóxicos fitossanitários. Available

$<$ http://extranet.agricultura.gov.br/agrofit cons/prin cipal_agrofit_cons>. Access: 07 jan. 2014.

BARROSO, A. L. L.; DAN, H. A.; PROCÓPIO, S. O.; TOLEDO, R. E. B.; SANDANIEL, C. R.; BRAZ, G. B. P.; CRUVINEL, K. L. Eficácia de herbicidas inibidores da ACCase no controle de gramíneas em lavouras de soja. Planta Daninha, ViçosaMG, v.28, n.1, p.149-157, 2010.

CAMPOS, C. F. de; MARTINS, D.; COSTA, A. C. P. R. da; PEREIRA, M. R. R.; CARDOSO, L. A.; MARTINS, C. C. Efeito de herbicidas na dessecação e germinação de sementes remanescentes de Lolium multiflorumL. Semina: Ciências agrárias, Londrina, v.33, n.6, p. 2067-2074, nov./dez. 2012.

DORS, C. A.; CHRISTOFFOLETI, P. J.; SANCHOTENE, D. M.; DIAS, A. C. R.; MANFRON, P. A.; DORNELES, S. H. B. Suscetibilidade de genótipos de Loliummultiflorum ao herbicida glyphosate. Planta Daninha, ViçosaMG, v.28, n.2, p.401-410, 2010.

EMBRAPA. Empresa Brasileira de Pesquisa Agropecuária. Sistema brasileiro de classificação de solos. 2ed. Rio de Janeiro: EMBRAPASPI, 2006. 412p.

GALVAN, J.; RIZZARDI, M. A.; SCHEFFERBASSO, S. Aspectos morfofisiológicos de biótipos de azevém (Loliummultiflorum) sensíveis e resistentes ao glyphosate. Planta Daninha. v.29, n.esp., p.1107-1112, 2011.
GEMELLI, A.; OLIVEIRA JUNIOR, R. S.; CONSTANTIN, J.; BRAZ, G. B. P.; JUMES, T. M. C.; GHENO, A. A.; RIOS, F. A.; FRANCHINI, L. H. M. Estratégias para o controle de capim-amargoso (Digitaria insularis)resistente ao glyphosate na cultura do milho safrinha. Revista Brasileira de Herbicidas, Maringá, v.12, n.2, p.162-170, maio/ago. 2013.

HEAP, I. The international survey of herbicide
resistant weeds. Available in: <www.weedscience.org.>. Access: 07 jan. 2014.

MARCHI, G.; MARCHI, E. C. S.; GUIMARÃES, T. G. Herbicidas: mecanismos de ação e uso. Planaltina: Embrapa Cerrados, 2008. p.36. (Documentos)

MELO, M. S. C.; ROSA, L. E.; BRUNHARO, C. A. C. G.; NICOLAI, M.; CHRISTOFFOLETI, P. J. Alternativas para o controle químico de capim-amargoso (Digitaria insularis) resistente ao glyphosate. Revista Brasileira de Herbicidas, Maringá, v.11, n.2, p.195-203, maio/ago. 2012.

MOREIRA, M. S.; MELO, M. S. C.; CARVALHO, S. J. P.; NICOLAI, M.; CHRISTOFFOLETI, P. J. Herbicidas alternativos para controle de biótipos de Conyza bonariensis e $C$. canadenses resistentes ao glyphosate. Planta Daninha, Viçosa-MG, v.28, n.1, p.167-175, 2010.

ROMAN, E. S.; VARGAS, L.; RIZZARDI, M. A.; MATTEI, R. W. Resistência de azevém (Lolium multiflorum) ao herbicida glyphosate. Planta Daninha, Viçosa-MG, v.22, n.2, p.301-306, 2004.

RUAS, R. A. A.; LIMA, J. C. L.; APPELT, M. F.; DEZORDI, L. R. Controle de Brachiaria decumbens Stapf com adição de uréia à caldo do glifosato. Pesquisa Agropecuária Tropical, Goiânia, v.42, n.4, p.455-461, out./dez. 2012.

VARGAS, L.; ROMAN, E. S.; RIZZARDI, M. A.; SILVA, V. C. Identificação de biótipos de azevém (Lolium multiflorum) resistentes ao herbicida glifosato em pomares de maça. Planta Daninha, Viçosa-MG, v.22, n.4, p.617-622, 2004.

VIDAL, R.; RAINERO, H. P.; KALSING, A.; TREZZI, M. M. Prospección de las combinaciones de herbicidas para prevenir malezas tolerantes $x$ resistentes al glifosato. Planta Daninha. Viçosa-MG, v.28, n.1, p.159-165, 2010. 